\title{
THE ROLE OF CORPORATE GOVERNANCE IN THE EFFECT EARNINGS MANAGEMENT HAS ON FIRM VALUE
}

\author{
Surifah \\ Faculty of Economics, Universitas Cokroaminoto Yogyakarta, Indonesia \\ (surifahganis@yahoo.com)
}

\begin{abstract}
Previous researchers found that managers have conducted opportunistic earnings management (Abdolmohammadi et al., 2010; Crocker and Slemrod, 2007; Cornett et al., 2009; Jaggi et al., 2009). Corporate Governance (CG) is one of the instruments to overcome, or at least to minimize, earnings management. This research aims to provide empirical evidence about the effect of $C G$ and earnings management on firm value, and the role of $C G$ in the effect earnings management has on firm value. This research is needed, to explain the effectiveness of CG's implementation by influencing earnings management, in order to lead to more efficient earnings management.

This study uses national commercial banks' data listed on the Indonesian Stock Exchange for the period 2006-2013. The research sample consists of 29 banks over an 8 year period, with a total of 232 observations. The research variable consists of the value of the firm, measured by Tobin's $Q$ as the dependent variable, real activity-based earnings management and accrual-based earnings management as the independent variables and corporate governance, measured by the CG index, as a moderating variable.

The results show that the CG index has a robust relationship with performance, controlled by both the ownership concentration's level and the size of the bank. Corporate governance has positive effects on firm value. The bigger the corporate governance disclosure score is, the higher the market value of the bank becomes. These results indicate that markets respond to the corporate governance's disclosure, so the company's market price increases. The results show that the CG index reinforces the positive influence of Accrual-based Earnings Management (AEM) and Real Earnings Management (REM) on the performance. These results indicate that corporate governance practices are able to steer earnings management away from the opportunistic and into the efficiency spectrum.
\end{abstract}

Keywords: corporate governance, earnings management, firm value

\section{INTRODUCTION}

Previous research has found that managers have conducted opportunistic earnings management (Abdolmohammadi et al., 2010; Crocker and Slemrod, 2007; Cornett et al., 2009; Jaggi et al.,2009). Therefore, it is important for companies to implement a Corporate Governance (CG) system to steer earnings management away from the opportunistic and into the efficiency spectrum. Earnings management is an accounting policy or action, chosen by a manager, to affect earnings to achieve certain goals (Scott, 2012). Earnings management is distinguished by its two perspectives, namely good and bad earnings management (Scott, 2012), or efficient and opportunistic earnings management (Gunny, 2010; Cornett et al., 2009).

Efficient earnings management is indicated by the increasing value of the firm, including an increase in its earnings' persistence (Gunny, 2010), so that earnings can be predicted, and they can become a signal for the improved quality of the earnings (Jara and López, 2011). Opportunistic earnings management is indicated by the increasing prosperity of the management, insiders, as well as the controlling shareholder(s). Previous research proved the existence of opportunistic earnings management (i.e. Abdolmohammadi et al., 2010; Crocker and Slemrod, 2007; Cornett et al., 2009; Jaggi et al., 2009). 
Earnings management is often used by the management and insiders, as well as the controlling shareholders, to expropriate the costs of the other stakeholders. For example, the related-party sales of goods and services could be used opportunistically to manage earnings upwards in the pre-IPO period (Aharony, Wang and Yuan, 2010). They also provide evidence that such behavior may be motivated by the prospect of tunneling opportunities in the postIPO period, i.e., exploiting the economic resources from the minority shareholders for the benefit of the parent company (Aharony et al., 2010). The salary rate of a manager (CEO) is based on earnings management, which means that the higher-paid managers, based on their financial performance, are less likely to report loan loss provisions while realizing greater profits from securities (Cornett et al.2009).

Executives of Northern Telecom (NT) designed their company's earnings to earn cash bonuses. They got a bonus of more than $\$ 50$ million in mid-2003 from NT, although in April 2004 NT reported a decline in earnings, and sacked its chief executive. This incident at NT also shows how the miss-statement of financial statements can become costly for companies (Crocker and Slemrod, 2007). Opportunistic earnings management is done by an insider or the controlling shareholders to maximize their interests (Abdolmohammadi et al., 2010; Jaggi et al., 2009). Abdolmohammadi et al. (2010) found that the earnings management of familycontrolled companies in Norway was generally in decline, compared to that of non-family companies. However, the high-leverage condition of family companies shows a strong tendency to perform earnings management by increasing the earnings, compared to that of the non-family companies.

The objective of CG is to protect the rights of stakeholders from their manager's expropriation, and that of the insiders and controlling shareholders. This expropriation can be done with earnings management. Corporate governance is used to describe all of the influences affecting the processes for appointing those who decide how operational control is exercised to produce goods and services, and all the external influences affecting operations or the controllers (Turnbull, 2000). Based on these definitions, CG can be used to protect the rights of all the stakeholders from expropriation by managers, insiders, and controlling shareholders, through earnings management. Therefore, CG is expected to direct the earnings management from the opportunistic spectrum into the efficiency spectrum. What is CG's role in strengthening the positive effect of earnings management on firm value? Can CG weaken the negative effect of earnings management on firm value? This research aims to answer these questions. The purpose of this research is to provide empirical evidence that: 1) $\mathrm{CG}$ and earnings management influence the value of a company; 2) that CG has a role in strengthening or weakening the effects of earnings management on firm value.

This research is important because research about the role of $\mathrm{CG}$ in strengthening or weakening the effect on bank's firm value has not received much attention from previous researchers. This research will be able to explain the effectiveness of CG's implementation in influencing earnings management, in order to lead to efficient earnings management. Some previous research about earnings management in the banking industry has been conducted by Cohen et al. (2014) and Leventis and Dimitropoulos (2012). Before 2007, the increase of a potential higher stock market risk was caused by the banks aggressiveness on earnings management, by which financial crises are evaluated through large weekly stock price "crashes" and the pattern of full-year returns (Cohen et al., 2014). A study by Shen and Huang (2013) investigated how earnings management influences credit ratings, and thus the cost of debt, using bank data from 85 countries. The results indicate that raters would downgrade the ratings when they perceived earnings management, after controlling for any other potential determinants of banks' credit ratings, implying that earnings management increases borrowing costs (Shen and Huang, 2013). 
The research about corporate governance, expropriation, earnings management and the firm value of banks in Indonesia becomes an interesting study for several reasons: First, Indonesia represents a country with emerging markets and the best-practice mechanism of CG has not been as strong there as in developed countries. Second, phenomena indicating expropriation by the controlling shareholders were found in the Indonesian banking system in 1998, when 16 banks were closed and seven banks were suspended, as well as the Bank Century scandal in 2008. These phenomena were supported by previous research, which found that expropriations by controlling shareholders existed (Claessens, Djankov, Fan, and Lang, 1999; Faccio and Lang, 2002; Haw, Hu, Hwang, and Wu, 2004; Siregar, 2008; Achmad et all, 2009). Third, the banking industry is one of the highly regulated industries, therefore, the banks should have CG best practices, lower expropriation by the controlling shareholders, and higher performance. Yet, some facts show that the phenomenon of expropriation by the controlling shareholder still exists in Indonesian banking.

The theoretical contributions of this research are: 1) Adding to the literature on the role of CG in strengthening or weakening the effect of real and accrual earnings management in banks in Indonesia; 2) making the use of the corporate governance's index measurement mandatory by regulation and voluntarily for the banks in Indonesia. The practical contributions are explained as follows: Earnings management is often used as a tool to conceal the private benefits received by managers, insiders, and the controlling shareholder (Cornett et al., 2009; Crocker and Slemrod, 2007; Sweeney, 1994; Defond and Jiambalvo, 1991; Abdolmohammadi et al., 2010; Jaggi et al., 2009; Prencipe et al., 2008; Wright et al., 2006). Thus, research into the role of corporate governance in strengthening/weakening the influence of earnings management and the value of the company will help business practitioners, investors, financial analysts, and the Government of Indonesia to evaluate the effectiveness of corporate governance in influencing earnings management practices, in order to enhance shareholders' value.

\section{LITERATURE REVIEW}

\section{The Agency Theory}

The agency theory is based on the assumption that each of the parties involved in a contract wants to maximize their interests. In the companies with highly concentrated levels of ownership, the agency conflict might occur between the controlling shareholder and the noncontrolling shareholders (Almeida and Wolfenzon 2006; Claessens et al., 1999; Giovannini, 2010; La Porta et al., 1999; Morck and Yeung, 2003; Oswald et al., 2009; Villalonga and Amit, 2006). This agency conflict is known as a Type II agency conflict.

This research is based on the assumption in the agency theory that the agency conflict in the banking sector in Indonesia may occur between the controlling shareholders and non-controlling shareholders, customers, and the Financial Services Authority (Otoritas Jasa Keuangan), and the Deposit Insurance Agency (Lembaga Penjamin Simpanan). In the case of Bank Century, its controlling shareholders performed expropriation, while the losers were its customers and the government, which guaranteed the majority of the customer funds ${ }^{1}$. Therefore, this research involves two control variables, which are family control and nonfamily control, in the relationship between earnings management, corporate governance and firm value.

\section{Earnings Management and Firm Value}

"Earnings management is the choice made by a manager regarding the accounting policies, or

\footnotetext{
${ }^{1}$ Bank Century was declared to be a failed bank on 20 November 2008 (Investigation report of BPK No.64/LHP/XV/11/ 2009). Data from the police shows that the Bank Century lost 1.18 trillion rupiah. Rp276.7 billion flowing to Robert Tantular, Rp248.44 billion to Anton Tantular and Rp853.971 billion to Hartawan Alui. (Robert Tantular and Hartawan Alui are sons-in-law of Sukanta Tanudjaja (Vivanews.com, 2008).
} 
actions that affect earnings, so as to achieve some specific earnings objective" (Scott, 2012). Earnings management can be conducted together with the accounting policy choices (Accruals Earnings Management/AEM) or the real activity (Real Earnings Management/REM). Examples of AEM are the choice of the depreciation or amortization methods, the timing of revenue recognition, warranty cost determinations, inventory valuations, and recognition of nonrecurring and extraordinary items. Examples of REM are the expenditure on advertizing, research and development costs, and fixed assets disposition expenses (Scott, 2012: 424).

Earnings management can be opportunistic and efficient by its nature. Earnings management influences performance by its two perspectives: Positive and negative influences. This study suspects that earnings management based on real activities, e.g.: Freezing out and tunneling (of real earnings management) will negatively affect the performance, while earnings management based on accruals will positively influence performance. This is caused by the fact that the phenomenon of the ownership structure of Indonesian companies are concentrated, pyramid-like, cross-holding, and controlled by the family (Claessens et al., 2000; Fan and Wong, 2000; Lukviarman 2004; Siregar, 2006; Sanjaya, 2010; Surifah, 2011). Such ownership structures provide strong incentives for the controlling shareholders to expropriate the company's resources at the cost of the noncontrolling shareholders (Gilson andGordon 2003, Villalonga and Amit, 2006), and this is associated with low performance and low firm value (Claessens et al., 2000; La Porta et al. 2002; Zhu and Ma, 2009).

Expropriation by the controlling shareholders can be done in three ways (Gilson and Gordon, 2003): 1) Through the company's operating policies, such as salary expenses, its pension fund, bonuses, and not distributing dividends; 2) through a freezing-out, by selling shares at a cheaper price to companies in the controlling shareholders group; 3) through the company's contract policy (tunneling), such as an unreasonable transfer price, the transfer of assets from the company to the controlling shareholder at a cheaper price, or the use of company assets as collateral.

These forms of expropriation cannot be manipulated by earnings management based on a discretionary accrual that is reversed ${ }^{2}$ between periods in the nature. Therefore a controlling shareholder would be more interested in using real earnings management to conceal permanent expropriations. Thus, it is reasonable to suspect that real earnings management is more opportunistic and will negatively affect the firm's value. Real earnings management in this research consists of earnings management through interest expenses and discretionary expenses, therefore the hypotheses statements are as follows:

H1.a.: Real earnings management through interest expenses has a negative relationship with firm value.

H1.b.: Real earnings management through discretionary expenses has a negative relationship with firm value

Conversely, if the controlling shareholders or managers are not motivated to do an expropriation, their information can be used to improve the efficiency of the contract. Therefore, if they are forced to perform earnings management, this earnings management will be used to provide flexibility for the managers or controlling shareholders to protect themselves, and for their company to anticipate unexpected events, so they do not inflict any financial loss to the parties involved in the contract (Scott, 2012). The type of earnings management which makes it possible to maximize the efficiency of the contract is accrual earnings management,

\footnotetext{
${ }^{2}$ Earnings management was often proxy with a pure accounting decision such as change in accounting procedures (Watts and Zimmerman, 1986); accrual accounting (McNichols and Wilson, 1988), and abnormal accruals (Jones, 1991) which all interperiod reversely. The use of sum of the years digit depreciation method leads to depreciation charge in the first year will be larger compared to the next periods. This means that expenses which are reported higher in the previous years will be reversed in the next years by reporting the smaller depreciation expenses.
} 
because it is not a permanent one, and it will be inversed every time-period (Dechow, 1994; Jones, 1991; Scott, 2012). Earnings management is often used as a proxy by using pure accounting decisions, such as changes in abnormal accruals (Dechow, 1994; Jones, 1991), so that all of them are reversed between periods. Therefore, this research assumes that accruals earnings management will be a positive influence on firm value and the hypothesis would be as follows:

H1.c: Accruals earnings management has a positive relationship with firm value.

\section{The Influence of Corporate Governance on Performance}

Previous studies found that good governance has a positive effect on firm value and operating performance (Brown and Caylor, 2006; Durnev and Kim, 2005; Gompers et al., 2003; Klapper and Love, 2002; Rehman and Mangla, 2012). Corporate governance variables significantly influence a bank's performance in all the sectors, except for foreign banks (Rehman and Mangla, 2012). Corporate governance scores relate positively to the value of Tobin's Q (Brown and Caylor (2006)). The companies in the US that are more powerful at protecting the rights of their shareholders have a better operating performance and higher market value (Gompers et al., 2001). Good governance has a positive relationship with the market value and operating performance (Klapper and Love, 2002). The more transparent and better corporate governance ranked companies will be highly valued in the stock market (Durnev and Kim, 2005).

Corporate governance mechanisms, such as the size of the board of directors and the board of director's independence have a positive relationship with a firm's performance (Ibrahim and Samad, 2011). The independence of the board of directors from the firm's founding family, and the financial interests of the members of the board of directors, have a positive impact on performance (Filatotchev et al., 2005). Based on previous research, this research suspected that corporate governance has a positive effect on the performance of banks listed on the Indonesian Stock Exchange. So:

$\mathrm{H} 2$ : Corporate governance has a positive relationship with firm value.

\section{The Role of CG on The Effect Earnings Management has on Firm Value}

The banking industry is a highly regulated industry. The government, through Bank Indonesia, has established special regulations regarding the implementation of good corporate governance for banks (Peraturan BI No.8/14/PBI 2006). In addition, Bank Indonesia also regulates the self-assessment of Good Corporate Governance (GCG) with the primary objective of improving the implementation of GCG by the banks (SE No.9/12/DPNP 2007). Some regulations have been issued to protect stakeholders from the opportunistic behavior of management or controlling owners, i.e. regulations on the maximum limit for shareholding in commercial and Islamic banks (Peraturan BI No.14/6/PBI 2012), lending limits for the commercial banks (Peraturan BI No.7/3/PBI 2005), and the fit-andproper test for the Islamic Banks (Peraturan BI No.14/6/PBI 2012). Any opportunistic behavior could create private benefits for some, to the cost of the other party, otherwise known as expropriation.

Based on the above description, it can be summarized that: 1) various regulations have been issued by the Government of Indonesia to improve GCG, 2) the results of previous research find a strong positive relationship between good governance and operating performance and firm value (Rehman and Mangla, 2012; Brown and Caylor, 2006; Gompers et al., 2003; Klapper and Love, 2002; Durnev and Kim, 2005). Therefore, this research assumes that corporate governance directs opportunistic earnings management towards efficient earnings management, so earnings management has a positive effect on firm value. Therefore, this research assumes that CG can strengthen the positive effect, or weaken the negative effects, of earnings management on the firm value of the banks and the hypothesis can be stated as follows: 
H3: CG can strengthen the positive relationship, or weaken the negative relationship, of earnings management on firm value.

\section{RESEARCH METHOD}

\section{Data, Population and Research Sample}

This study uses the data on the national commercial banks listed on the Indonesian Stock Exchange, for the period from 2006 to 2013 . The year 2006 was chosen as the beginning of the study, because the first regulation regarding the implementation of good corporate governance for commercial banks were issued in 2006, which was regulation number 8/14/PBI/2006. The end of the selected data period is 2013, because the data collection were done in March 2015, so the latest data that could be obtained are data from the financial statements of 2013.

The research data is secondary data obtained from the listed firms' annual reports. Data from the financial statements and ownership details are obtained from the Indonesian banking directory and Bank Indonesia. This research uses purposive sampling. The criteria are that the firms produced annual reports and annual financial statements, and did not merge between the years 2006and 2013. Based on those criteria, the researcher could obtain a total sample of 29 banks listed on the Indonesian Stock Exchange.

\section{The Research Variable and Measurement}

This research consists of a dependent variable, two independent variables, a moderating variable, and control variables. The dependent variable is the value of the bank (the firm value). The independent variables are earnings management based on real activities and discretionary accruals. The moderation variable is corporate governance. The control variables are the family's control, size and concentration of ownership.

\subsection{Firm Value}

The value of the bank (the firm value) is measured by the value of the bank or its firm value. Previous research has also measured firm values, using Tobin's Q (Abbas and Rizwan,
2007). The advantage of using Tobin's $Q$ is that the difficult problem of estimating the rate of return can be avoided. Moreover, for $q$ to be meaningful, one needs accurate measures of both the market value and replacement cost of a firm's assets. It is usually possible to get an accurate estimate for the market value of a firm's assets, by summing the values of the securities that a firm has issued, such as stocks and bonds. It is much more difficult to obtain an estimate of the replacement costs of its assets, unless markets for used equipment exist (Abbas and Rizwan, 2007).

Tobin's $Q$ is the ratio of the total value of the securities of a company, such as its stocks and bonds, to the replacement value of its assets (Kim and Statman, 2012). Companies with high Tobin's Q values are companies that are judged by investors to have a bright future. Tobin's Q reflects the perception of a firm's current and future profitability, in the eyes of investors (Kim and Statman, 2012). Tobin's Q is the ratio of the market value to the replacement cost of the firm assets of the banks, which can be calculated as follows (Abbas and Rizwan, 2007):

$$
\mathrm{FV}=((\mathrm{MVE}+\mathrm{BVA})-\mathrm{BVE}) / \mathrm{BVA}
$$

Note:

FV : Firm Value (Tobin's Q)

MVE : Market value of equity is obtained from the number of shares outstanding multiplied by the stock market price per share.

BVA : Book value of assets

BVE : Book value of equity

\subsection{Earnings management}

Earnings management is measured with real activity-based and discretionary accrual-based earnings management. Real Earnings Management (REM) is derived from the model of Roychowdhury (2006), and adapted for the banking business. Roychowdhury's model (2006) uses three forms of REM, which are REM through the costs of production, REM through discretionary expenses, and REM through the cash flow from operations. This research uses only REM through interest and discretionary expenses. Interest expenses are the 
main expenses in the banking business, while the discretionary expenses are expenses that are determined by management policies. Cash flow is used as a measure of REM, because an operating cash flow has an impact on the interest and discretionary expenses. In other words, if the interest and discretionary expenses are high, the cash flow from operations will be low, and vice versa. This research also uses the accrual earnings management specific to the banks (Beaver and Engel 1996), which was also used by Rahmawati (2006).

\subsection{Real Earnings Management}

Regression models, which were used to obtain the real earnings management, are as follows by Surifah (2014):

$$
\begin{aligned}
& {\frac{I E_{i t}}{A}}_{i t-1}=\alpha_{0}+\alpha_{1}\left(\frac{1}{A_{i t}}\right)+\beta_{1}\left(\frac{I R_{i t}}{A_{i t-1}}\right)+ \\
& \beta_{2}\left(\frac{\Delta I R_{i t}}{A_{i t-1}}\right)+\beta_{3}\left(\frac{\Delta I R_{i t-1}}{A_{i t-1}}\right)+\varepsilon_{i t} \\
& \frac{D E_{i t}}{A_{i t}}=\alpha_{0}+\alpha_{1}\left(\frac{1}{A_{i t-1}}\right)+\beta_{1}\left(\frac{I R_{i t-1}}{A_{i t-1}}\right)+\varepsilon_{i t}
\end{aligned}
$$

Note:

${\frac{I E_{i t}}{A}}_{i t-1} \quad \begin{aligned} & \text { : Interest expenses of bank } \mathrm{i} \text { in year } \mathrm{t} \\ & \text { scaled by the total assets of bank } \mathrm{i} \text { in }\end{aligned}$ year $\mathrm{t}-1$.

$\frac{D E_{i t}}{A_{i t}} \quad$ : Discretionary expenses of bank $\mathrm{i}$ in year $t$ scaled by the total assets of bank $\mathrm{i}$ in year $\mathrm{t}-1$..

$\alpha_{1}\left(\frac{1}{A_{i t}}\right)$ : Intercept scaled with the total assets of bank $i$ in year $t-1$, thus the cash flow from operations does not have value 0 when the trading and lag trading value are 0 .

$\frac{I R_{i t}}{A_{i t-1}} \quad:$ Interest revenue of bank $\mathrm{i}$ in year $\mathrm{t}$ scaled by the total assets of banki in year $\mathrm{t}-1$

$\frac{\Delta I R_{i t}}{A_{i t-1}} \quad$ : Interest revenue of bank $\mathrm{i}$ in year $\mathrm{t}$ minus the interestrevenue of bank $i$ in year $\mathrm{t}-1$ scaled by the assets of bank $\mathrm{i}$ in year $\mathrm{t}-1$

$\varepsilon_{i t} \quad:$ Error term for bank i in the year t.

The regression models in Equations 1 and 2 are implemented by all the company samples (cross-sectional) for the entire period, because the number of banks listed on the Indonesian Stock Exchange is relatively small (with the number of samples only being 29 per year). The abnormal values for interest and discretionary expenses are not absolute, because the positive and negative values have different meanings. The banks' interest expenses, as well as the discretionary expenses, are higher, compared to the industry average, as indicated by the appropriate positive value for each abnormal return. This indicates that the banks are less efficient. Some previous research that tests the real earnings management has also done the same thing (Roychowdhury, 2006; Gunny, 2010; Cohen et al., 2008; Hashemi and Rabiee, 2011).

It is a general convention in the literature to include a scaled intercept, $\alpha_{1(1 / A i t),}$ when estimating non-discretionary accruals (Roychowdhury, 2006). This avoids a spurious correlation between scaled interest expenses and scaled interest revenues, due to variations in the scaling variable, total assets. The researcher also included an unscaled intercept, $\alpha_{0}$, to ensure that the mean abnormal interest expenses for every industry-year are zero. Including the intercepts allows the average $\mathrm{IE}_{\mathrm{it}} / \mathrm{A}_{\mathrm{t}-1}$ for a particular industry year to be non-zero, even when the primary explanatory variables in the model, interest revenues and change-in-interest revenues, are zero (Roychowdhury, 2006).

The regression result showed the normal interest expenses and the normal discretionary expenses. Real earnings management is obtained from the abnormal interest expenses and the abnormal discretionary expenses. The abnormal interest and discretionary expenses are calculated from the actual interest expenses, and the actual discretionary expenses are scaled by the total assets of the previous year, and are reduced by the normal of the interest and discretionary expenses. The normal of the interest and discretionary expenses is calculated by using the coefficient estimated from Equations 1 and 2.

\subsection{Accruals Earnings Management in the Bank}

Accrual earnings management used in this research is a special accrual model for banks 
(Beaver and Engel, 1996) which was also used by Rahmawati (2006). Discretionary accruals are a proxy for earnings management. Total Accruals (TA), Non-Discretionary Accruals (NDA) and Discretionary Accrual (DA) are calculated by the following equations:

$$
\begin{aligned}
\mathrm{TA}_{\mathrm{it}} & = \\
\mathrm{TA}_{\mathrm{it}} & = \\
& \left.\alpha_{3} \mathrm{NPA}_{\mathrm{it}}+\alpha_{4} \Delta \mathrm{NPA}_{\mathrm{it}+1}\right]+\varepsilon_{\mathrm{it}}+\mathrm{DA}_{\mathrm{it}} \\
\mathrm{DA}_{\mathrm{it}}= & \mathrm{TA}_{\mathrm{it}}-\left[\alpha_{0}+\alpha_{1} \mathrm{CO}_{\mathrm{it}}+\alpha_{2} \mathrm{LOAN}_{\mathrm{it}}+\right. \\
& \left.\alpha_{3} \mathrm{NPA}_{\mathrm{it}}+\alpha_{4} \Delta \mathrm{NPA}_{\mathrm{it}+1}\right]
\end{aligned}
$$

Note:

$\mathrm{TA}_{\mathrm{it}} \quad$ : Total accruals = balance of allowance for earning assets possible losses (saldo penyisihan penghapusan aktiva produktif) of bank i in the year t.

$D A_{i t}$ : Discretionary accrual of bank $\mathrm{i}$ in year $\mathrm{t}$.

$\mathrm{CO}_{\text {it }} \quad$ : Loan charge-offs of bank $\mathrm{i}$ in year $\mathrm{t}$. LOAN $_{\text {it }}$ : Outstanding loans of bank $\mathrm{i}$ in year $\mathrm{t}$

NPA : Non-performing assets consist of productive assets based on collectability levels: a) Specific oversight, b) sub-standard, c) doubtful, and d) loss.

$\triangle \mathrm{NPA}:$ Difference in non-performing assets $\mathrm{t}+1$ and non-performing assets $\mathrm{t}+$ all the variables deflated with the book value of equity plus provision for doubtful debt. Thus to calculate the accrual earnings management for the proxy: $\mathrm{DA}_{\text {it }}=\mathrm{TA}_{\mathrm{it}}-\mathrm{NDA}_{\mathrm{it}}$

$\mathrm{NDA}_{\text {it }}$ : Non-discretionary accruals of bank $\mathrm{i}$ in year $\mathrm{t}$.

$\varepsilon_{\text {it }} \quad: \mathrm{DA}_{\mathrm{it}}$

All the variables are deflated by the Gross Book Value (GBV), which is the equity book value plus the loans' financial loss reserve (gross value). So, the discretionary accruals can also be an error term (divergence/residual value) of the Equation model 4 above, or $\mathrm{DA}_{i t}=\mathrm{TA}_{\mathrm{it}}-\mathrm{NDA}_{\mathrm{it}}$. This research used the discretionary and nondiscretionary components of the provision for loan losses, because this account was the main accrual in the banking industry (Beaver and Engel, 1996).

\subsection{Corporate Governance Index}

Corporate governance is measured using the Corporate Governance Index (CGI). The CGI is obtained by calculating the scores of the CGI per the score of the maximum CGI. For example, a bank's CGI score is 50 , and the maximum score is 60. Its means that the implementation(3f) CGI $=(50 / 60) \times 100 \%=83.33 \%\left(\right.$ See attachment $\alpha_{1} \mathrm{CO}_{\text {it }}+\alpha_{2} \mathrm{LOA}$ about CG index).

\subsection{Control Variable}

The control variables of this study are family control, the level of ownerships' concentration and firm size. The proxy of ownerships' concentration is the largest shareholder, measured as the percentage of shares held by the largest owner ${ }^{3}$. This proxy was also used by Heugens et al. (2009), La Porta et al. (1999); and Jara and López (2011). This research uses such a proxy since the ownership of Indonesian banks is highly concentrated. About $93 \%$ of the owners have more than $30 \%$ of the shares in Indonesian banks (Surifah2014). Firm size is measured by the log of total assets. This proxy has also been used by Jara and López (2011); Maury (2006); and Haw et al., (2004).

The proxy of family control is either the dummy variable family or non-family. A bank is considered to be family-controlled if the largest shareholder is an individual or group of people, or if Bank Indonesia mentions that its ultimate shareholder is an individual or group of people. Non-family banks are split into three categories, which are: Non-family banks controlled by the government, non-family banks controlled by private institutions, and non-family banks controlled by foreign institutions. A bank becomes a controlled government bank if its biggest shareholder is the government. A bank becomes a private institution-controlled bank if the largest shareholders are private institutions.

\footnotetext{
${ }^{3}$ The proxy of ownership concentration is the largest shareholder, since the ownership of Indonesian banks is highly concentrated. The ownership of less than $15 \%$ is about $0.14 \%$, whereas ownership of between $15 \%$ to $30 \%$ is about $6.75 \%$, and about $93 \%$ of owners have more than $30 \%$ of the shares in Indonesian banks.
} 
A bank becomes a foreign institution-controlled bank if its largest shareholder is a foreign institution.

\section{Model Specification}

The model used panel data to test the hypotheses, utilizing a data multiple regression model, because the data are time series and cross-sectional. The procedure uses a Generalized Least Square (GLS) method. This procedure transforms the original variables in such a way that the transformed variables satisfy the assumptions of the classical model, and then applying OLS to them is known as the method for Generalized Least Squares (GLS). In short, GLS is OLS performed on the transformed variables that satisfies the standard least-squares' assumptions. The estimators thus obtained are known as GLS estimators, and it is these estimators that are BLUE $^{4}$ (Best Linear Unbiased Estimator) (Gujarati and Porter, 2009). The research equation models used to test Hypotheses 1, 2, and 3 are as follows:

$$
\begin{aligned}
\mathrm{FV}_{\mathrm{it}}= & \alpha+\beta_{1} \mathrm{AEM}_{\mathrm{it}}+\beta_{2} \mathrm{CGI}_{\mathrm{it}}+\beta_{3} \text { Fam }_{\mathrm{it}}+ \\
& \beta_{4} \text { Largest }_{\mathrm{it}}+\beta_{5} \text { Size }+\varepsilon \\
\mathrm{FV}_{\mathrm{it}}= & \alpha+\beta_{1} \mathrm{RIE}_{\mathrm{it}}+\beta_{2} \mathrm{RDE}_{\mathrm{it}}+\beta_{3} \mathrm{CGI}_{\mathrm{it}}+ \\
& \beta_{4} \text { Fam }_{\mathrm{it}}+\beta_{5} \text { Largest }_{\mathrm{it}}+\beta_{6} \text { Size }+\varepsilon \\
\mathrm{FV}_{\mathrm{it}}= & \alpha+\beta_{1} \mathrm{CGI}_{\mathrm{it}}+\beta_{2} \mathrm{CGI}_{\mathrm{it}}{ }^{*} \mathrm{AEM}_{\mathrm{it}}+ \\
& \beta_{3} \text { Largest }_{\mathrm{it}}+\beta_{4} \text { Size }_{\mathrm{it}}+\varepsilon \\
\mathrm{FV}_{\mathrm{it}}= & \alpha+\beta_{1} \mathrm{CGI}_{\mathrm{it}}+\beta_{2} \mathrm{CGI}_{\mathrm{it}}{ }^{*} \mathrm{RIE}_{\mathrm{it}}+ \\
& \beta_{3} \mathrm{CGI}^{*} \mathrm{RDE}+\beta_{4} \text { Largest }_{\mathrm{it}}+\beta_{5} \\
& \text { Size }_{\mathrm{it}}+\varepsilon
\end{aligned}
$$

\section{Note:}

$\mathrm{FV}_{\text {it }} \quad$ : Firm value of bank i, in year t.

$\mathrm{AEM}_{\mathrm{it}} \quad$ : Accruals earnings management of bank $\mathrm{i}$, in year $\mathrm{t}$.

\footnotetext{
${ }^{4}$ 1. It is linear, that is, a linear function of a random variable, such as the dependent variable $Y$ in the regression model.2. It is unbiased, that is, its average or expected value, $E\left(\beta_{2}\right)$, is equal to the true value, $\boldsymbol{B}_{2} .3$. It has minimum variance in the class of all such linear unbiased estimators; an unbiased estimator with the least variance is known as an efficient estimator (Gujarati and Porter 2009).
}

RIE $_{\text {it }} \quad$ : Real interest expense of bank $\mathrm{i}$, in year $\mathrm{t}$.

$\mathrm{RDE}_{\mathrm{it}} \quad$ : Real discretionary expenses of bank $\mathrm{i}$, in year $\mathrm{t}$.

$\mathrm{CGI}_{\text {it }} \quad$ : Corporate governance index of bank $\mathrm{i}$, in year $\mathrm{t}$.

Fam $_{\text {it }} \quad$ : Family control of bank i, in year $\mathrm{t}$. The family control as an included group, and the non- family control as an excluded group.

Largest $_{i t}$ : The largest of shareholders of bank $i$, in year t. This is the proxy of ownership concentration.

Size $_{i t} \quad$ : Size of the bank of bank $\mathrm{i}$, in year $\mathrm{t}$. $=\log$ total assets of bank $\mathrm{i}$, in year $\mathrm{t}$.

\section{The Research Model and Technique Analysis}

The research model is presented in Figure 1. The figure shows that the dependent variable of this research is the value of the bank, the independent variable is earnings management and the moderation variable is corporate governance (see attachment about the CG index).

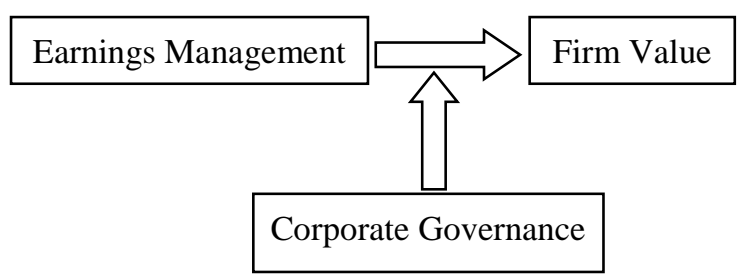

Figure 1. The research model

\section{RESULTS AND DISCUSSION}

\section{Descriptive Statistics}

The results of the descriptive statistics indicate that the total number of observations is 232 banks, which consists of 29 bank samples per year for 8 years. The number of banks controlled by a family comprises of 96 observations (41.37\%), those controlled by the government are 37 observations (15.94\%), those controlled by private institutions make up 71 observations $(30.60 \%)$, and those controlled by foreign institution comprise 30 observations (12.93\%). All variables have a deviation standard of less than 1 (one), which means there are no data outliers. 
Table 1.a. Descriptive statistics of the number of observation and percentage

\begin{tabular}{lcc}
\hline Variable & $\mathbf{N}$ & $\mathbf{( \% )}$ \\
\hline Fam & 96 & 41.37 \\
Gov & 37 & 15.95 \\
Priv & 71 & 30.60 \\
Forg & 30 & 12.93 \\
\hline Total N & 232 & $100 \%$ \\
\hline
\end{tabular}

Note:

Fam :Family control (banks controlled by family),

Gov : Government control,

Priv : Private control,

Forg : Foreign control.

The level of the implementation of corporate governance is high at an average of $84.83 \%$. This may be because the index for corporate governance is based on Indonesian government regulations for banking. The ownership structure is highly concentrated, since on average the largest share ownership is $59.72 \%$.

\section{The Effect of Real Earnings Management on Firm Value}

The results in Table 2 show that real earnings management through interest expenses does not have a relationship with firm value. These results remained consistent after the relationship was controlled by the controlling family, the concentration of ownership (largest) and the bank size. This result does not confirm the prediction; therefore, Hypothesis 1a is rejected. This is probably because RIE has not come to the market's attention, so this is similar to a normal business practice, and it does not have a relationship with the market's value of the bank.

This result differs from previous research which have indicated that the phenomenon of the ownership structure of Indonesian companies is concentrated, pyramidal, cross-holding, and controlled by the family (Claessens et al., 2000; Fan and Wong, 2000; Lukviarman, 2004; Siregar, 2006; Sanjaya, 2010; Surifah, 2011). Such ownership structures provide strong incentives for controlling shareholders to expropriate funds (through real earnings management) toward the company's resources, at the cost of the non-controlling shareholders (Gilson andGordon, 2003 and Villalonga and Amit, 2006) and this is associated with low performance and low firm value (Claessens et al., 2000; La Porta et al., 2002; Zhu and Ma, 2009).

The results in Table 2 show that real earnings management through discretionary expenses has a positive relationship with the firm value. These results remained consistent after the relationship was controlled by the controlling family, the concentration of ownership (largest) and the bank size. This means that the greater the discretionary expenses, the greater the value of the bank on the market. These results do not confirm the prediction, so Hypothesis $1 \mathrm{~b}$ is rejected.

Table 1.b. Descriptive statistics of the research variables

\begin{tabular}{lccccc}
\hline \multicolumn{1}{c}{ Variable } & N & Min & Max. & Mean & Std. Deviation \\
\hline CGI & 232 & $61.67 \%$ & $96.67 \%$ & $85.19 \%$ & 0.0701 \\
RIE & 232 & $-55.26 \%$ & $59.96 \%$ & $02.26 \%$ & 0.0639 \\
RDE & 232 & $-13.58 \%$ & $43.74 \%$ & $04.75 \%$ & 0.0425 \\
AEM & 232 & $-27.20 \%$ & $196.8 \%$ & $02.76 \%$ & 0.2115 \\
CGI*RIE & 232 & $-11.92 \%$ & $15.38 \%$ & $02,40 \%$ & 0.0294 \\
GCI*RDE & 232 & $-10.19 \%$ & $34.99 \%$ & $00.40 \%$ & 0.0341 \\
GCI*AEM & 232 & $-22.28 \%$ & $154.2 \%$ & $00.03 \%$ & 0.1704 \\
Largest & 232 & $15.42 \%$ & $100.0 \%$ & $59.72 \%$ & 0.2034 \\
Size (log total assets) & 232 & 11.621 & 14.950 & 13.327 & 0.7741 \\
\hline
\end{tabular}

Note: CGI: Corporate Governance Index, RIE: Real earnings management through interest expenses, RDE: Real earnings management through discretionary expenses, AEM: Accruals earnings management, Largest: Ownership concentration, Size: Size of bank. 
Table 2. The effect of real earnings management and corporate governance on banks' values

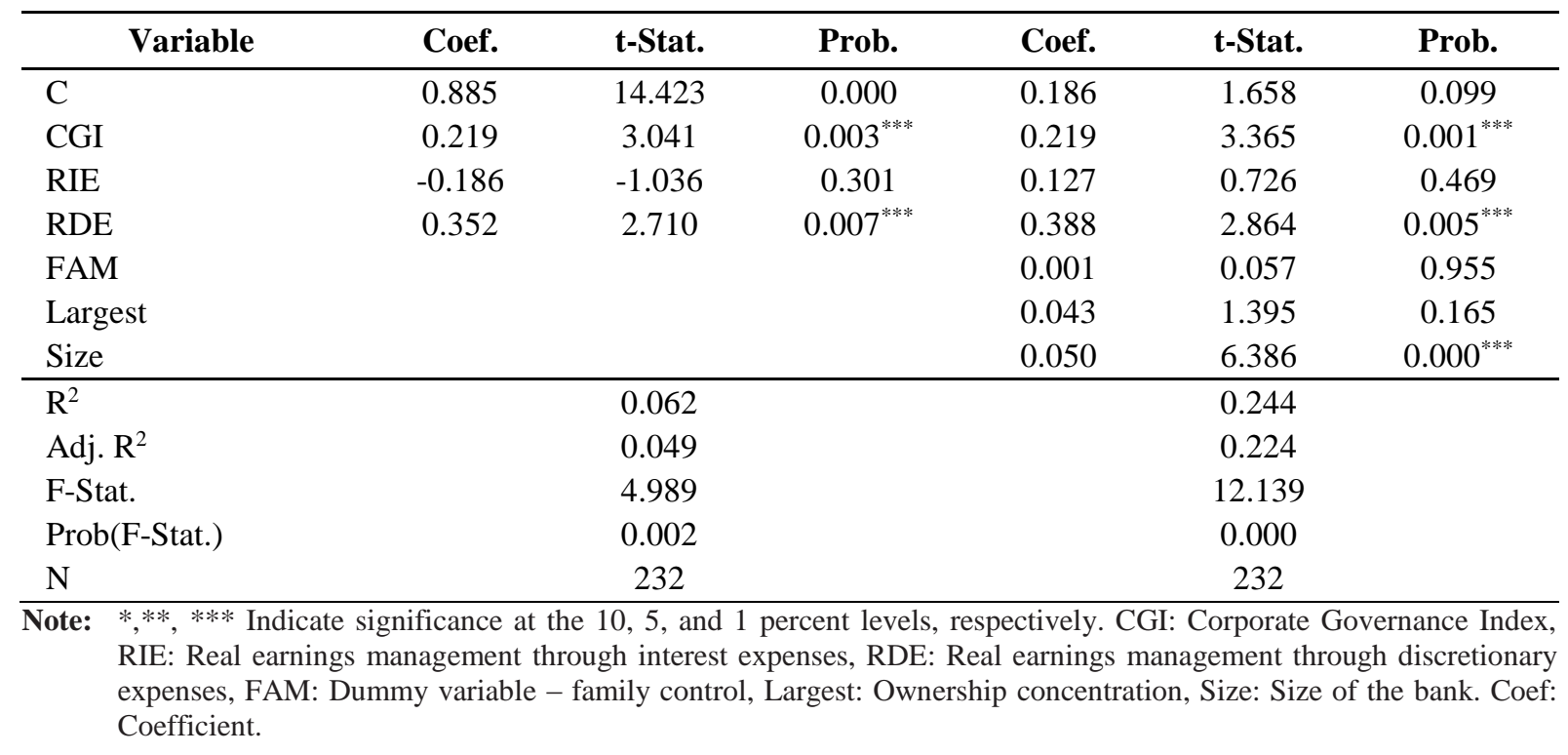

This finding is probably caused by the utilization of RIE by the managers to attain benefits, so RIE has a positive relationship with firm value. This result is consistent with the results of previous research conducted by Gunny (2010) who found that Real Manipulation (RM) activities to just meet earnings benchmarks are positively associated with future performance, compared to firms that do not use RM and miss their earnings benchmark by more than 0.01 . Firms that just meet their earnings benchmarks by engaging in Research and Development (R\&D) or Selling, General and Administrative (SG \& A) RM, have significantly higher subsequent industry-adjusted ROA than firms that do not engage in RM and just meet their earnings benchmarks (Gunny, 2010). In this setting, the results suggest earnings management via $R M$ is not opportunistic, but consistent with managers attaining benefits that allow for better future performance or signaling (Gunny, 2010).

Family control has no effect on the value of the banks. This result means that the market value of a family-controlled bank is not significantly different from that of a non-family bank. The level of ownership concentration does not have a relationship with the value of the banks, but the bank size has a positive effect on firm value. This result means that the bigger the bank is, the higher its market value will be.

\section{The Effect of Accrual Earnings Management on Firm Value}

The results in Table 3 show that at the 5\% significance level, Accruals Earnings Management (AEM) does not have a relationship with firm value, but at the $10 \%$ significance level, AEM has a positive effect on firm value. This result means that the bigger the AEM is, the greater the value will be on the market. These results remained consistent after the relationship was controlled by the controlling family, the concentration of ownership (largest) and the bank size. These results are consistent with Hypothesis 1c which states that accrual earnings management has a positive relationship with performance. These results indicate that the market does not care whether the banks perform accrual earnings management or not.

These results are consistent with the results of previous research conducted by Chang, Shen, and Fang (2008) who found that bank managers may use discretionary loan loss provisions to engage in earnings management when the nonperforming loans are at a high level. Yet, these results are inconsistent, with the results of previous research conducted by $\mathrm{Wu}$ et al. (2016). In their study, selected samples of ASEAN commercial banks from 2007 to 2014 were used, and banking performance through profitability and managerial efficiencies were 
analyzed. They found that loan loss provisions (as the proxy of earnings management) were negatively related to banking performance. The researcher suspects that this inconsistency is due to the difference in performance proxies. The researcher then used market performance, which is a firm's value, whereas Wu et al. (2016) used financial performance.

The results in Table 3 show that for the big sized banks, family control does not have a significant effect on firm value. This result also indicates that, for big sized banks, the market does not care whether the bank is controlled by a family or not. In contrast, for small sized banks, the market lacks confidence in them, therefore the size of bank has a relationship with the market value of a small bank and makes the market value lower than that of the non-family bank. The negative relationship of family control with the market's firm value is insignificant when size is included as a control variable.

\section{The Relationship of Corporate Governance with Firm Value}

The results in Tables 2, 3, and 4show that CGI has a positive effects on firm value. These results remained consistent after the relationship was controlled by the controlling family, the concentration of ownership (largest) and the bank size. These results support hypothesis 2 , which stated that corporate governance has a positive relationship with firm value. The higher the implementations of corporate governance are, the higher the market value of the bank is. These results confirm the previous research, which found that corporate governance has a positive relationship with the performance and the market value of the company (Rehman and Mangla, 2012; Brown and Caylor, 2006; Gompers et al., 2003; Klapper and Love, 2002; Durnev and Kim, 2005). These results indicate that the market responds to the disclosure of corporate governance, so the company's market price increases.

\section{The Role of CG on the Effect of Accruals Earnings Management on Firm Value}

The results in Table 4 indicate that CG strengthens the positive influence of AEM on a bank's value. These results are consistent with Hypothesis 3, which stated that CG can strengthen the positive relationship, or weaken the negative relationship, of earnings management on firm value, therefore the third hypothesis is supported by the data. These results indicate that corporate governance practices are able to drive the earnings management's opportunistic spectrum toward the efficiency spectrum.

Table 3. The effect of accruals earnings management and corporate governance on banks' values

\begin{tabular}{|c|c|c|c|c|c|c|}
\hline Variable & Coef. & t-Stat. & Prob. & Coef. & t-Stat. & Prob. \\
\hline $\mathrm{C}$ & 0.900 & 15.318 & 0.000 & 0.227 & 3.294 & 0.001 \\
\hline CGI & 0.201 & 2.822 & $0.005^{* * *}$ & 0.192 & 3.477 & $0.001^{* * *}$ \\
\hline AEM & 0.032 & 1.655 & $0.099^{*}$ & 0.031 & 1.715 & $0.088^{*}$ \\
\hline FAM & & & & 0.001 & 0.064 & 0.949 \\
\hline Largest & & & & 0.052 & 1.716 & $0.087^{*}$ \\
\hline Size & & & & 0.048 & 9.734 & $0.000^{* * *}$ \\
\hline $\mathrm{R}^{2}$ & & 0.035 & & & 0.217 & \\
\hline Adj. $R^{2}$ & & 0.027 & & & 0.199 & \\
\hline F-stat. & & 4.172 & & & 12.534 & \\
\hline Prob. (F-Stat.) & & 0.017 & & & 0.000 & \\
\hline $\mathrm{N}$ & & 232 & & & 232 & \\
\hline
\end{tabular}


These results are consistent with the results of previous research conducted by Nasution and Setiawan (2007), Leventis and Dimitropoulos (2012). Nasutian and Setiawan (2007) found that the corporate governance mechanisms, which are the size and composition of the boards of commissioners, and the existence of an audit committee, influenced the earnings management of public banks in Indonesia, which was detected by using the specific accrual model from Beaver and Engel (1996). They showed that mechanisms done by a company have succeeded in minimizing the earnings management practices, and corporate governance mechanisms have worked effectively to increase companies' performances (Nasution and Setiawan, 2007). Good corporate governance mechanisms should include a board of independent commissioners, an independent audit committee and managerial ownership, which all simultaneously can influence the earnings management in the banking industry (Rahmawati, 2013). She found that the board of independent commissioners negatively influenced the earnings management, while an independent audit committee and managerial ownership did not influence the earnings management. Banks with efficient corporate governance mechanisms report small positive incomes to a lesser extent than banks with weak governance efficiency. Also wellgoverned banks engage less in aggressive earnings management behavior, through the use of discretionary loan loss provisions and realized security gains and losses (Leventis and Dimitropoulos, 2012). Yet, this research is different to that of Nasution and Setiawan (2007), Rahmawati (2013), and Leventis and Dimitropoulos (2012), in terms of its CG measurement research model. Therefore, this research is expected to contribute to real earnings management measurements.

\section{CONCLUSION}

The real earnings management does not have a relationship with firm value, so it does not support the initial predictions. These results are probably caused by, firstly, banks in Indonesia having already implemented best practice corporate governance, so that real earnings management is used in an attempt to maximize the value of the company's contracts. Secondly, investors do not pay attention to real earnings management; therefore real earnings management does not have a negative relationship with the market value. These results differ from Surifah (2014) who found that REM has a negative relationship with the bank's financial performance. It is suspected that this inconsistency is due to the different performance proxies. This research uses market performance, which is the firm's value, whereas Surifah (2014) used financial performance.

Table 4. The role of CG on the effect of earnings management on firm value

\begin{tabular}{|c|c|c|c|c|c|c|}
\hline Variable & Coef. & t-Stat. & Prob. & Coef. & t-Stat. & Prob. \\
\hline $\mathrm{C}$ & 0.377 & 3.952 & 0.000 & 0.300 & 3.160 & 0.002 \\
\hline CGI & 0.138 & 2.623 & $0.009^{* * *}$ & 0.149 & 2.735 & $0.007^{* * *}$ \\
\hline CGI*AEM & 0.066 & 1.803 & $0.073^{*}$ & & & \\
\hline CGI*RIE & & & & 0.213 & 1.849 & $0.066^{*}$ \\
\hline CGI*RDE & & & & 0.531 & 3.561 & $0.001^{* * *}$ \\
\hline Largest & 0.062 & 2.999 & $0.003^{* * *}$ & 0.030 & 1.443 & 0.150 \\
\hline Size & 0.038 & 5.630 & $0.000^{* * *}$ & 0.044 & 6.730 & $0.000^{* * *}$ \\
\hline $\mathrm{R}^{2}$ & & 0.199 & & & 0.240 & \\
\hline Adj. $\mathrm{R}^{2}$ & & 0.185 & & & 0.223 & \\
\hline F-Stat. & & 14.094 & & & 14.272 & \\
\hline Prob (F-Stat.) & & 0.000 & & & 0.000 & \\
\hline $\mathrm{N}$ & & 232 & & & 232 & \\
\hline
\end{tabular}


The control variable of family control has no relationship with a bank's market value. This result means that the value of a family-controlled bank is not significantly different from that of a non-family-controlled bank. The level of concentration of ownership has no relationship with firm value. This result is also inconsistence with Surifah (2014) who found that family control and the level of ownership concentration have a negative effect on a bank's financial performance. The size of a bank has a positive relationship with firm value. This means that the bigger the bank is, the higher is its market value.

Corporate governance has a positive relationship with firm value, when the relationship is controlled by both the largest ownership and size. These results support the predictions. The higher the corporate governance disclosure score is, the higher is the firm value of the bank. These results confirm previous research, which found that corporate governance has a positive effect on the performance and market value of the company (Rehman and Mangla, 2012; Brown and Caylor, 2006; Gompers et al., 2003; Klapper and Love, 2002; Durnev and Kim, 2005). These results indicate that the market responds to the disclosure of corporate governance, therefore the firm's market price increases. The results also show that corporate governance strengthens the positive effect of accruals and real earnings management on firm value. These results indicate that corporate governance practices are able to drive earnings management from an opportunistic spectrum to an efficiency spectrum.

This research has several limitations. First, this research does not separate between earnings from operations and the change in earnings from earnings management practices. Second, this research measures performance using a market approach. Third, this research does not involve the bank's condition rating, since such data were not fully available. Based on those limitations, future research should start by using a more comprehensive performance measure, such as a balanced scorecard, and by considering other variables which affect a firm's performance, such as a bank's condition rating.

\section{BIBLIOGRAPHY}

Abbas, Z., and M.F. Rizwan, 2007. "Abnormal Accruals and Firm Value, Panel Data Analysis of Banking Industry of Pakistan."European Journal of Scientific Research, 17(4), 445-454.

Abdolmohammadi, M., E. Kvaal, and J.C. Langli, 2010. "Earnings management priorities of private family firms."Centre for Corporate Governance Research, 3.

Achmad, T., Rusmin, J. Neilson, and G. Tower, 2009. "The Iniquitous Influence of Family Ownership Structures on Corporate Performance." The Journal of Global Business Issues, 3 (1), 41-48.

Aharony, J., J. Wang, and H. Yuan, 2010. "Tunneling as an Incentive for Earnings Management during the IPO Process in China."Journal of Accounting and Public Policy, 29(1), 1-20.

Almeida, H.V. and D. Wolfenzon, 2006. "A theory of Pyramidal Ownership." The Journal of Finance, 61 (6), 2637-2680.

Ananchotikul, N., 2007. "Does Foreign Direct Investment really Improve Corporate Governance? Evidence from Thailand." Working Paper. University of California, Berkeley.

Beaver, W. H. and E.E. Engel, 1996. "Discretionary Behavior with Respect to Allowances for Loan Losses and the Bahavior of Security Prices."Journal of Accounting and Economics, 22(1-3), 177206.

Brown, L.D. and M.L. Caylor, 2006. "Corporate Governance and Firm Valuation. Journal of Accounting and Public Policy, 25 (4), 409434.

Chang, R.D., Shen, W.H. and C.J. Fang, 2008. "Discretionary Loan Loss Provisions and Earnings Management for the Banking Industry."International Business and Economics Research Journal7(3), 9-18.

Claessens, S., S. Djankov, J. Fan, and L. Lang, 1999. "Expropriation of Minority Shareholders in East Asia." available at: http:// ssrn.com/abstract=202390 May 10, 2014.

Claessens, S., Djankov, S. and L. Lang, 2000. "East Asian corporations. Heroes or villains" World Bank Discussion Paper No. 409. 
Cohen, D.A., A. Dey, and T.Z. Lys, 2008. "Real and Accrual-Based Earnings Management in the Pre and Post-Sarbanes-Oxley periods." The Accounting review, 83(3), 757-787.

Cohen, L.J., M. M. Cornett, A. J. Marcus and H. Tehranian, 2014. "Bank earnings management and tail Risk during the Financial Crisis." Journal of Money, Credit and Banking , 46(1), 171-197.

Cornett, M.M., J.J. McNutt, and H. Tehranian, 2009. "Corporate governance and earnings management at large U.S. bank holding companies." Journal of Corporate Finance, 15(4), 412-430.

Crocker, K.J. and J. Slemrod, 2007. "The economics of earnings manipulation and managerial compensation." The Rand Journal of Economics, 38(3), 698-713.

Dechow, P., 1994. "Accounting earnings and cash flow as measures of firm peprformance: The role of accounting accruals." Journal of Accounting of economics, 18, 342.

Durnev, A. and E.H. Kim, 2005. "To steal or not to steal: Firm attributes, legal environment, and valuation". The Journal of Finance, 60(3).

Faccio, M. and L.H.P. Lang, 2002. "The ultimate ownership of Western European". Journal of Financial economics, 65, 365-395.

Fan, J.P.H. and T.J. Wong, 2000. "Corporate ownership structure and the informativeness of accounting earnings in East Asia". Journal of Accounting Research, 43(1), 3572.

Filatotchev, I., Y.C. Lien, and J. Piesse, 2005. "Corporate governance and performance in publicly listed, family-controlled firms: Evidence from Taiwan". Asia Pacific Journal of Management, 22, 257-283.

Gilson, R.J. and J.N. Gordon, 2003. "Controlling-controlling shareholders". University of pennsulvania Law review, 152(2), 785-843.

Giovannini, R., 2010. "Corporate governance, family ownership and performance". Journal Management Governance, 14, 145166.

Gompers, P., J. Ishii, and A. Metrick, 2003.
"Corporate governance and equity prices". The Quarterly Journal of Economics, 107155.

Gujarati, D.N. and D.C. Porter, 2009. "Basic econometrics". Fifth Edition McGraw-Hill. New York america.

Gunny, K.A., 2010. "The relation between earnings management using real activities manipulation and future performance: Evidence from meeting earnings benchmarks". Contemporary Accounting Research, 27(3), 855-888.

Hashemi, S.A. and H. Rabiee, 2011. "The role of corporate governance in real earnings management: Evidence from Iran". Interdisciplinary Journal of Contemporary research in Business, 3(6), 848-858.

Haw, I.M., B. Hu, L.S. Hwang, and W. Wu, 2004. "Ultimate Ownership, Income Management, and Legal and Extra-Legal Institutions". Journal of Accounting Research, 42(2), 423-462.

Heugens, P.P.M.A.R., M. Van Essen, and J.H. Van Oosterhout, 2009. "Meta-Analyzing Ownership Concentration And Firm Performance In Asia: Towards A More Fine-Grained Understanding". Asia Pacific Journal Management, 26, 481-512.

Ibrahim, H. and F.A. Samad, 2011. "Corporate governance mechanisms and performance of public-listed family-ownership in Malaysia". International Journal of Economics and Finance, 3(1), 105-116.

Jaggi, B., S. Leung, and F. Gul, 2009. "Family control, board independence and earnings management: Evidence based on Hong Kong firms". Journal Accounting \& Public Policy, 28(4), 281-300.

Jara, M. and F.J. López, 2011. "Earnings management and contests for control: An analysis of European family firms". Journal of Centrum Cathedra, 4(1), 100-120.

Jones, J.J., 1991. "Earnings management during import relief investigations". Journal of Accounting Research, 29(2), 193-228.

Kim, Y. and M. Statman, 2012. "Do Corporations Invest Enough In Environmental Responsibility?". Journal Business Ethics, 105, 115-129.

Klapper, L.F. and I. Love, 2002. "Corporate 
Governance, Investor Protection, And Performance In Emerging Markets". available at: http://ssrn.com/abstract-id303979 June 10, 2013.

Laporan investigasi BPK No.64/LHP/XV/11, 2009. "Laporan hasil pemeriksaan investigasi atas kasus PT Bank Century, Tbk pada bank Indonesia, Lembaga Penjamin Simpanan, Komite Stabilitas Sistem Keuangan dan PT Bank Century Tbk. No. 64/LHP/XV/11/2009 (Investigation Report on Century Bank case, at Indonesia". Badan Pemeriksa Keuangan Republik Indonesia.

La Porta, R., F. Lopez-de-Silanes, A. Shleifer, and R Vishny, 2002. "Investor Protection And Corporate Valuation". The Journal of Finance, 57(3), 1147-1170.

La Porta, R., Lopez-de-silanes, and A.Shleifer, 1999. "Corporate Ownership Around The World". The Journal of Finance, 54(2), 471-517.

Leventis, S. and P. Dimitropoulos, 2012. "The role of corporate governance in earnings management: Experience from US banks". Journal of Applied Accounting, 13(2), 161177.

Lukviarman, N., 2004. "Ownership Structure And Firm Performance: The Case of Indonesia". Thesis. Curtin University of Technology.

Maury, B., 2006. "Family Ownership And Firm Performance: Empirical Evidence From Western European Corporations". Journal of Corparate Finance, 12, 321-341.

McNichols, M. and G.P. Wilson, 1988. "Earnings Management From The Provision Of Bad Debts". Journal of Accounting Research, 26, 1-31.

Morck, R. and B. Yeung, 2003. "Agency Problem In Large Family Business Groups". Enterpreneurship: Theory and Practice, 27(4), 367-382.

Nasution, M. and D. Setiawan, 2007. "Pengaruh Corporate Governance Terhadap Manajemen Laba Di Industri Perbankan Indonesia (The influence of corporate governance on earnings management in the Indonesian banking industry)". Simposium Nasional Akuntansi X. Makasar, 1-26.

Oswald, S.L., L.A. Muse, and M.W. Rutherford,
2009. "The Influence Of Large Stake Family Control On Performance: Is It Agency Or Entrenchment?". Journal of Small Business management, 47(1), 116135.

Peraturan_BI_No.14/6/PBI, 2012. "Peraturan Bank Indonesia tentang uji kemampuan dan kepatuhan bank syariah dan unit usaha syariah (Bank Indonesia Regulation concerning fit and proper test of sharia banks and sharia business units)". Bank Indonesia.

Peraturan_BI_No.7/3/PBI, 2005. Peraturan Bank Indonesia tentang batas maksimum pemberian kredit bank umum (Bank Indonesia Regulation concerning the maximum crediting limits for commercial banks)". Bank Indonesia.

Peraturan_BI_No.8/14/PBI, 2006. "Peraturan Bank Indonesia tentang pelaksanaan good corporate governance bagi bank umum (Bank Indonesia regulation concerning the implementation of good corporate governance for commercial banks)". Bank Indonesia.

Rahmawati, 2006. "Pengaruh Asimetri Informasi Pada Hubungan Antara Regulasi Perbankan Dan Manajemen Laba Serta Dampaknya Terhadap Kinerja Saham (The Influence of Information Asymmetry on The Relationship Between Banking Regulation And Earnings Management And Its Impact on" . Unpublished Dissertation, Post-Graduate Programme. Yogyakarta: UGM.

Rahmawati, H.I., 2013. "Pengaruh Good Corporate Governance Terhadap Manajemen Laba Pada Perusahaan Perbankan (The Influence of Good Corporate Governance on Earnings Management In Banking Companies)". Accounting Analysis Journal, 2(1), 9-18.

Rehman, R.U. and I.U Mangla, 2012. "Does Corporate Governance Influence Banking Performance?". Journal of Leadership, Accountability and Ethical, 9(3), 86-93.

Roychowdhury, S., 2006. "Earnings Management Through Real Activities Manipulation". Journal of Accounting and Economics, 42, 335-370.

Sanjaya, I.P.S., 2010. "Efek Entrenchment Dan Alignment Pada Manajemen Laba (The 
Effects Of Entrenchment And Alignment On Earnings Management)". Unpublished Dissertation, Post-Graduate Programme. Yogyakarta: UGM.

Scott, W.R., 2012. "Financial Accounting Theory". Prentice Hall Canada, p.424.

SE_No.9/12/DPNP, 2007. "Surat Edaran Tentang Pelaksanaan Good Corporate Governance Bagi Bank Umum (Regulations On The Implementation Of Good Corporate Governance For Commercial Banks)". Bank Indonesia.

Shen, C.-H. and Y.L. Huang, 2013. "Effects Of Earnings Management On Bank Cost Of Debt". Accounting and Finance, 53(1), 265300 .

Siregar, B., 2006. "Pemisahan Hak Aliran Kas Dan Hak Kontrol Dalam Struktur Kepemilikan Ultimat (Separation Of Cash Flow Rights And Control Rights In The Structure Of Ultimate Ownership)". Unpublished Dissertation, Post-Graduate Programme. Yogyakarta: UGM.

Siregar, B., 2008. "Pengaruh Pemisahan Hak Aliran Kas dan Hak Kontrol Terhadap Dividen (The Effect of Separation of Cash Flow Rights and Control Right on Dividends". Jurnal Riset Akuntansi indonesia, 11(2), 158-185.

Surifah, 2011. "Corporate Governance dan Manajemen Laba: Pengaruh Presiden Komisaris Independen dan Komite Audit Independen (Corporate Governance and Earnings Management: the Influence of the Chairman of The Board of Directors And an Independent Audit Committee)". Kinerja, 12(2), 145-159.
Surifah, 2014. "Konsentrasi Kepemilikan, Manajemen Laba dan Kinerja Perbankan Indonesia (Concentration Of Ownership, Earnings Management and Performance of Indonesian Banking)". Unpublished Dissertation, Post-Graduate Programme. Surakarta: UNS.

Turnbull, S., 2000. "Corporate governance: Theoris, challenges, and paradigms". Gouvernement D'enterprise: Theories, Enjeux et paradigmes or available at: ssrn $i d=220954$ May 15, 2010, 1(1), 11-43.

Villalonga, B. and Amit, R., 2006. "How Do Family Ownership, Control and Management Affect Firm Value?." Journal of Financial Economics, 80, 385-417.

Vivanews.com, 2008. "Robert Tantular Kendalikan Antaboga - Bersama Kerabatnya Robert Menguasai 82,18\% Persen Saham Antaboga". Vivanews.Com, Selasa 2 Desember 2008. available at: (http://www.vavanews.com December 2, 2008.

Watts, R.L. and J.L. Zimmerman, 1986. "Positive Accounting Theory". Englewood Cliffs, NJ: Prentice Hall.

Wu, Y.C., W.K.T. Irene, L. Wen-Min, N. Mohammad, and L.K. Qian, 2016. "The Impact Of Earnings Management On The Performance Of Asean Banks". Economic Modelling, 53, 156-165.

Zhu, Z. and H. Ma, 2009. "Multiple PrincipalAgent Relationships, Corporate-Control Mechanisms And Expropriation Through Related Party Transactions: Evidence from China". International Research Journal of Finance and Economics, 31, 141-163. 


\section{Attachment 1: \\ Corporate Governance Bank Index}

\begin{tabular}{|c|c|c|}
\hline No. & Questions & Scoring \\
\hline \multicolumn{3}{|c|}{ Board of Directors } \\
\hline 1 & $\begin{array}{l}\text { The number of independent directors is divided by all the board of directors } \\
\text { (Peraturan_BI_No.8/14/PBI 2006). }\end{array}$ & $\begin{array}{l}\geq 50 \% 1 \\
<50 \% 0\end{array}$ \\
\hline 2 & The president director is independent (SE_No.9/12/DPNP 2007). & Yes 1 , no 0 \\
\hline 3 & $\begin{array}{l}\text { Accounting and financial competences of the independent board of } \\
\text { directors(SE_No.9/12/DPNP 2007). }\end{array}$ & Yes 1 , no 0 \\
\hline 4 & The number of people on the board of directors(SE_No.9/12/DPNP 2007). & $3 \geq 1.3<0$ \\
\hline 5 & The number of meetings of the board of directors(SE_No.9/12/DPNP 2007). & $4 \geq 1,<4,0$ \\
\hline 6 & Meeting presence of directors board (SE_No.9/12/DPNP 2007) & $\begin{array}{l}\geq 50 \%, 1 \\
<50 \%, 0\end{array}$ \\
\hline 7 & Is there a special meeting of the independent board of directors? (Ananchotikul 2007). & Yes 1 , no 0 \\
\hline 8 & $\begin{array}{l}\text { Board of Directors membershave } 5 \% \text { (five percent) or more of shares of the bank or other } \\
\text { domestic and foreign banks or companies disclosed?(Peraturan_BI_No.8/14/PBI 2006). }\end{array}$ & Yes 1 , no 0 \\
\hline 9 & $\begin{array}{l}\text { Are Board of Directors members financial and family relationships to other board of } \\
\text { director's members, to management and/or controlling stockholder disclosed? }\end{array}$ & Yes 1 , no 0 \\
\hline 10 & Are salary, honorarium, and aid for board members of directors disclosed? & Yes 1 , no 0 \\
\hline
\end{tabular}

\begin{tabular}{|c|c|c|}
\hline \multicolumn{3}{|c|}{ Management } \\
\hline & The number of management members (SE_No.9/12/DPNP 2007). & $\begin{array}{l}3 \geq 1 \\
<3=0\end{array}$ \\
\hline 12 & Bank-operating experience of most management members. & $\begin{array}{l}5 \text { years } 1, \leq 5 \\
\text { years } 0\end{array}$ \\
\hline 13 & $\begin{array}{l}\text { The management members individually or collectively own more than } 25 \% \text { (twenty five } \\
\text { percent) of shares of deposited capital of other companies (SE_No.9/12/DPNP 2007)? }\end{array}$ & No 1 , yes 0 \\
\hline 14 & $\begin{array}{l}\text { Are the management members possession of5\% (five percent or more) of shares of the bank } \\
\text { or other domestic and foreign banks or companies disclosed? (Peraturan_BI_No.8/14/PBI } \\
\text { 2006) }\end{array}$ & Yes 1 , no 0 \\
\hline 15 & $\begin{array}{l}\text { Are remuneration and other facilities received by the management } \\
\text { disclosed?(SE_No.9/12/DPNP 2007). }\end{array}$ & Yes 1 , no 0 \\
\hline 16 & $\begin{array}{l}\text { All members of management stated their financial and family relationships to board of } \\
\text { directors members, to management members and/or to the controlling stockholder. }\end{array}$ & Yes 1 , no 0 \\
\hline & $\begin{array}{l}\text { All members of management passed the fit and proper test and the BI approved } \\
\text { them(SE_No.9/12/DPNP 2007). }\end{array}$ & $\begin{array}{l}\text { All passed } 1 \text {, } \\
\text { no } 0\end{array}$ \\
\hline 18 & $\begin{array}{l}\text { The president director or managing director is independent from controlling stockholders, } \\
\text { does not have financial, administrating, and family relationship to stockholders. }\end{array}$ & $\begin{array}{l}\text { Indept. } 1 \text {, not } \\
\text { indpt. } 0\end{array}$ \\
\hline
\end{tabular}

\section{Committees}

19 Is the auditing committee led by an independent person? (SE_No.9/12/DPNP 2007).

20 Is the presence of auditing committee meeting announced? (SE_No.9/12/DPNP 2007).

Yes 1 , No 0

21 Are roles and responsibilities of committees clearly described? (SE_No.9/12/DPNP 2007).

Yes 1 , no 0

22 Are independent auditing committees competent in accounting and financing and others

Yes 1 , no 0 competent in law and banking(SE_No.9/12/DPNP 2007)?

23 Members of independent auditing committees are independent directors?.

24 The number of independent auditing committee meetings per year (Ananchotikul 2007).

25 Did the auditing committee monitor and evaluate the auditing plan and realization and the follow-up of the auditing result to judge internal controlling sufficiency and the process of financial report? (SE_No.9/12/DPNP 2007).

26 Is risk-monitoring committee led by an independent director? (SE_No.9/12/DPNP 2007).

27 Members of the risk monitoring committee are independent directors and

Yes 1 , no 0

Yes 1 , no 0

$\geq 12,1$

$<120$

Yes 1 , no 0 independent?(SE_No.9/12/DPNP 2007).

28 Are the roles and responsibilities of risk monitoring committee clearly described?(SE_No.9/12/DPNP 2007).

29 Is the attendance at a meeting of risk monitoring committee announced? (Ananchotikul, 2007).

Yes 1 , no 0

Yes 1, no 0

Yes 1 , no 0

Yes 1 , no 0 


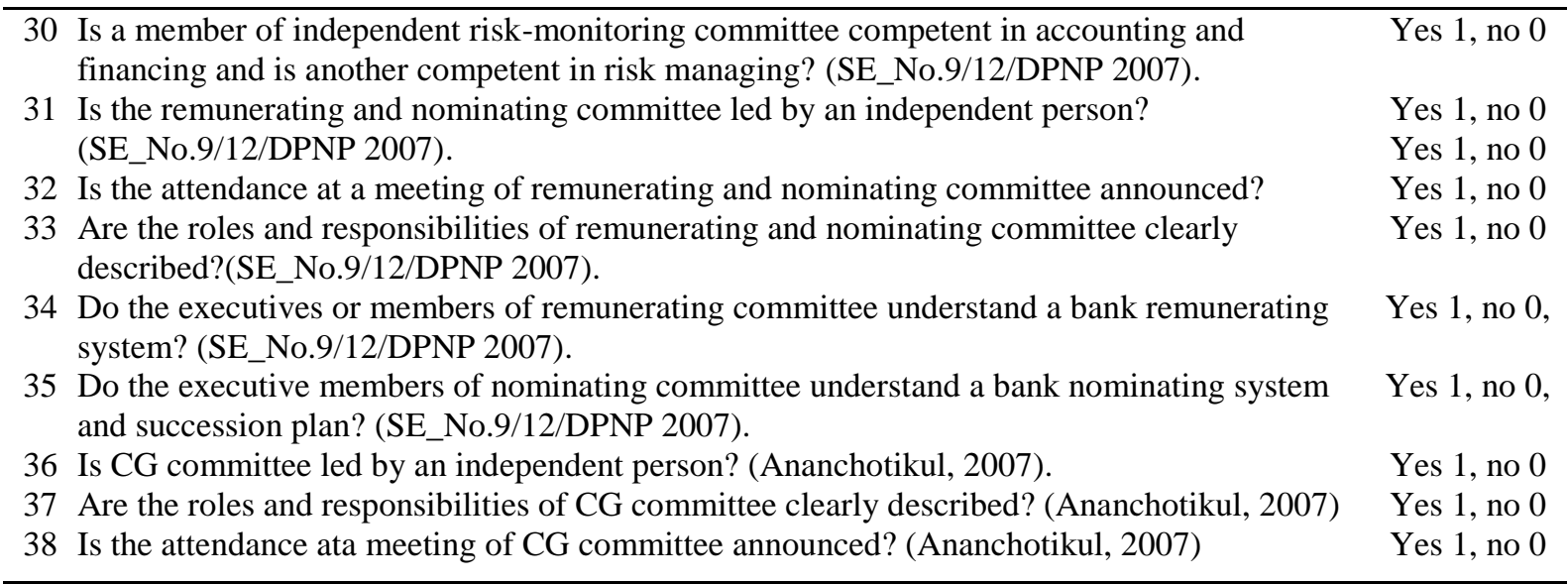

Controlling Issue: Does the bank publish controlling issues below?

$\begin{array}{llr}39 \text { Organizational and environmental controlling. } & \text { Yes 1, no 0 } \\ \text { (Ananchotikul, 2007). } & \text { Yes 1, no 0 } \\ 40 \text { Risk management (SE_No.9/12/DPNP 2007). } & \text { Yes 1, no 0 } \\ 41 \text { Controlling management activity (Ananchotikul, 2007). } & \text { Yes 1, no 0 }\end{array}$

\begin{tabular}{llr}
\hline & Stockholder's rights & \\
\hline 43 & Does the company carry out the annual RUPS(SE_No.9/12/DPNP 2007)? & Yes 1, no 0 \\
44 & Does the company send the letter of RUPS to stockholders a week before carrying out? & Yes 1, no 0, \\
45 & Does the company impose one share-one vote? (Ramral, 2011). & Yes 1, no 0 \\
46 & Does the company disclose its dividend policy? (Ramral, 2011). & Yes 1, no 0 \\
47 & Does the bank explain the reason to determine the dividend at a certain level. & Yes 1, no 0 \\
\hline
\end{tabular}

\section{Announcement and Transparency}

48 Does the bank announce in detail its transactions with others affiliates?

49 Does the bank have a clearly written policy, system, and procedure on how to provide funds to related parties and provide large funding and monitoring and problem solving?

50 Does the bank disclose the company group structure? (Ananchotikul, 2007)

51 Does the bank disclose the stockholders structure? (Ananchotikul, 2007).

52 Does the bank disclose the organizational structure of company? (Ananchotikul, 2007).

53 Does the annual report explain the principles and realization of CG?.

54 Does the bank announce the grouping of preferred stockholders of a family or an economic unit? (Ananchotikul, 2007).

55 Is there, in the managing director's report, that he ensured, controlled, monitored, and decided the steps for the bank to impose the principle of carefulness according the BI's rule and other prevalent laws including the bank's commitment to the BI and other authorities?

56 The bank has an internal auditing standard operating procedure (SPFAIB) (SE_No.9/12/DPNP 2007).

57 The bank made an internal auditing certificate(SE_No.9/12/DPNP 2007).

58 The bank made a task force for internal auditing and a manual for internal auditing (SE_No.9/12/DPNP 2007).

59 Is there a report of the bank's realized internal auditing? (SE_No.9/12/DPNP 2007).

60 Auditor's opinion (SE_No.9/12/DPNP 2007).

Yes 1 , no 0

Yes 1, no 0

Yes 1, no 0

Yes 1, no 0

Yes 1, no 0

Yes 1, no 0

Yes 1, no 0

Yes 1 , no 0

Yes 1 , no 0

Yes 1, no 0

Yes 1, no 0

Yes 1, no 0 others 0

Notice: The Journal of Indonesian Economy and Business including the Editors decline all errors and flaws found in this article. Authors are fully responsible for them. 